\title{
Guest Comment: The Drake University Conference on Undergraduate Research in the Sciences
}

\author{
Heidi Sleister, Department of Biology \\ Charles Nelson, Department of Physics and Astronomy \\ Maria Bohorquez, Department of Chemistry \\ Drake University \\ 2507 University Avenue \\ Des Moines, lowa 50311-4505 USA
}

\section{BACKGROUND}

The road to developing a vigorous undergraduate research program often begins with a leap of faith. Those taking the first steps must naturally assume that their colleagues share similar goals and levels of commitment in training students for careers in science. In addition, a collaborative effort between administration and departments is required to establish undergraduate research as a campus-wide priority. So it was that a small group of faculty committed to establishing a culture of undergraduate research at Drake University began plans for an internal conference showcasing the scientific results of students and faculty.

Drake University is a small midwestern school with strong academic programs. It consists of a liberal arts college and several other professional schools including, notably, the College of Pharmacy. Drake is highly regarded as a regional university, however the strength of its science programs is not as visible as programs such as fine arts and humanities.

An initiative to change this was triggered in February of 2003, when a small group of Drake science faculty (including the authors) attended a conference organized by the Council on Undergraduate Research (CUR) entitled "The Art of Grantsmanship." It was apparent that many of the conference attendees came from primarily undergraduate institutions that strongly support and proactively encourage their research efforts with students. Although collaborative learning among students, faculty, and staff is an important part of Drake's mission, the infrastructure for undergraduate research at the time was clearly not as well developed as the examples reported on at CUR. We returned from the meeting determined to enhance the research environment at Drake.

The first step in this process was organizing a "research day" in the form of a high visibility mini-conference, where students and faculty could present their research in a series of talks and posters. The primary goal was to raise awareness in the overall Drake community of the research activities of science faculty and students. Additional goals were to provide students with experience presenting the results of their research in a public setting and to create avenues for crosstalk among the different scientific fields attending the conference. Our hope was that this event would be a catalyst for students, faculty and the administration to join in supporting undergraduate research across campus.

\section{PLANNING THE CONFERENCE}

\section{a. Organizing Committee}

Although the Drake University Conference on Undergraduate Research in the Sciences (DUCURS) was scheduled for late in the spring semester, planning began in the fall. After a large group of science and mathematics faculty met to brainstorm ideas, a smaller organizing committee, 
consisting of 8 faculty members and 9 students, representing every science and mathematics department on campus, was formed. The event was announced to the campus community and a rough estimate was made of the number of faculty and students interested in participating. In addition to the organizing committee, a few faculty members and many more students were recruited to assist with particular aspects of the conference (e.g., registration, poster hanging, prize drawings, conference room setup, poster awards, publicity, and technology). The bulk of the organization of DUCURS took place during the two months leading up to the event.

\section{b. Abstract Submission}

One month prior to the conference, an official announcement and call for abstracts for DUCURS were sent to all faculty, staff, and students. Students and faculty from all eight science and mathematics departments and programs: biochemistry cell \& molecular biology (BCMB), biology, chemistry, environmental science \& policy (ENSP), mathematics \& computer science, pharmaceutical sciences, physics \& astronomy, and psychology submitted abstracts for a total of 40 posters and 8 oral presentations. Abstracts were compiled into a booklet including a conference schedule, a list of sponsors, a map of the conference rooms, a list of prize contributors, an index, and acknowledgements. This information and instructions for registration were made available on a DUCURS website (www.drake.edu/ducurs). Presenters were contacted with guidelines for preparing posters and talks.

\section{c. Publicizing the Event}

After the first official invitation for DUCURS, postcard invitations were delivered to the science and mathematics faculty a week before the event. To interest students in participating, advertisements promising food and prizes and an article describing the conference were published in the student-run university newspaper. Sidewalk-chalked invitations also greeted students around campus. The Deans of the
College of Arts and Sciences and Pharmacy sent emails to faculty encouraging them to release students from class to participate in DUCURS, and faculty announced the event in their classes. In addition, students were offered incentives to participate in the conference. Some instructors offered extra credit and/or allowed students to miss class if they viewed at least four posters. A mechanism for verifying attendance was devised in the form of a checklist that students brought to each poster to be initialed by the poster author. The checklist served as a "get out of class free" pass for some students, and also as an entry into prize drawings. More importantly, the checklist was designed to encourage interactions between meeting attendees and poster presenters.

\section{d. Conference budget and sponsors}

The total budget for DUCURS was approximately $\$ 1,950$. By far, food was the greatest expense $(\$ 1,305)$. Rolls, muffins, and beverages were available in the morning, and lunch was provided for all authors. Food was kept close to the posters to promote discussions. Additional costs included advertising (\$340), printing of conference booklets ( $\$ 250$ for two hundred 28-page booklets), and registration materials (\$55). Approximately one-third of the funding for DUCURS was received from Drake University's College of Arts and Sciences, one-third was received from the lowa Space Grant Consortium/NASA, and the remaining one-third was received from the College of Pharmacy and Drake University departments of biology, chemistry, mathematics \& computer science, physics \& astronomy, and psychology. In addition to these sponsors of the event, many local businesses donated prizes that were awarded at the conference.

\section{THE CONFERENCE}

The tremendous amount of planning and work that was required for DUCURS was rewarded by a very successful event. The conference was held on Friday, April 9, 2004 in Parents Hall of Olmsted, Drake University's student union. Following is a schedule and a description of the event. 


\section{Schedule}

8:15 Registration

8:45 Welcome, Opening Remarks

9:15 Student Oral Presentations

10:15 Poster Session

11:30 Lunch

12:15 Poster Session

1:00 Student Oral Presentations

2:00 Break

2:15 Science/Math Quiz Bowl

2:45 Awards, Closing

Following registration and a welcome by the organizing committee, the Dean of the College of Arts and Sciences discussed the importance of research in the undergraduate experience.

Two sessions with four 15-minutes oral presentations each were held with faculty taking on the duties of session chairs. Students were originally sought to be session chairs, but some were uncomfortable with the idea of informing a fellow student that his/her speaking time was ending. The quality of the presentations was excellent. Student presenters were pleased that individuals from a broad range of scientific fields asked many questions. A highlight was the connection established between a math student who presented a talk on loop theory and pharmacists interested in protein structure.

Two sessions were scheduled for viewing 40 posters, 35 of which had students as the primary authors and presenters. To promote interactions of individuals from different departments, posters were shuffled so that adjacent posters came from different disciplines. Of the 35 student posters, 32 described research projects conducted at Drake University, and three represented work done at external REU's. The top two student posters were selected for awards. The remarkably high level of participation across disciplines was evident in that at least one poster was presented from every science and mathematics department on campus (see table). Furthermore, $77 \%$ of science faculty members sponsored a poster and/or talk, an impressive number considering that some faculty members were on sabbatical leave at the time. The amount of interest in the posters was overwhelming. Student presenters described their research projects to an interdisciplinary audience. One student commented, "DUCURS... opened my eyes to all of the research being done on campus." Importantly, professors, the Deans of the Colleges of Arts and Sciences and Pharmacy, and the Provost interacted with many students, leaving them with the impression that their work is important.

To extend interactions between students and faculty and to provide continuity between morning and afternoon sessions, lunch was provided on-site for authors. Before wrapping up the event, students hosted a quiz bowl game in which two teams of 8 students each competed for prizes by answering questions across disciplines. The conference ended with further recognition of the excellent collaborative research being done by faculty and students at Drake University. Furthermore, ideas to increase this effort as well as improve the sciences at Drake were discussed.

\section{POST-CONFERENCE REFLECTIONS AND OUTCOMES}

The first conference on undergraduate research in the sciences at Drake University was an overwhelming success and the beginning of a new annual event. Reflection on our experiences provides us with several ideas that can be implemented in future years. We share some of these suggestions here for readers who are also involved in organizing such an event.

- Start planning early.

- Develop a website that is dedicated for the event.

- Enlist lots of help. Include as many students as possible, and seek administrative assistance.

- Schedule a well-known keynote speaker for the conference who can also interact with students.

- Coordinate the event with alumni and admissions offices.

- Include a section in the conference booklet that highlights the research interests and scholarship activities of Drake University faculty and staff. 


\begin{tabular}{lcccc}
\hline & & \multicolumn{2}{c}{ POSTERS } & TALKS \\
\hline $\begin{array}{c}\text { Departments and } \\
\text { Programs }\end{array}$ & $\begin{array}{c}\text { Number of faculty } \\
\text { sponsors (\%) }\end{array}$ & $\begin{array}{c}\text { Number of } \\
\text { posters }\end{array}$ & $\begin{array}{c}\text { Number of student } \\
\text { authors }\end{array}$ & $\begin{array}{c}\text { Number of } \\
\text { talks }\end{array}$ \\
BCMB $^{1}$ & $2(100 \%)$ & 3 & 16 & 1 \\
Biology & $6(60 \%)$ & 13 & 14 & 1 \\
Chemistry & $4(67 \%)$ & 6 & 6 & - \\
ENSP & $2(100 \%)$ & 1 & 2 & - \\
Math \& CS & $2(20 \%)$ & 3 & 1 & 1 \\
Pharmacy Science & $5(71 \%)$ & 6 & 6 & 3 \\
Physics \& Astronomy & $4(80 \%)$ & 7 & 11 & 2 \\
Psychology & $5(63 \%)$ & 7 & 14 & - \\
Total & 28 & 40 & 69 & 8 \\
\hline
\end{tabular}

${ }^{1}$ Biochemistry, Cell and Molecular Biology

- Expand the conference to include all disciplines.

Although DUCURS was only a 1-day conference, a number of positive outcomes were realized.

- The quantity, quality, and diversity of science and math undergraduate research projects were impressive. Student and faculty researchers were recognized for excellence in research by their peers and administrators.

- The conference allowed students to practice giving oral and poster presentations for an interdisciplinary audience.

- As stated by one student participant, the conference "made Drake's math and science departments a community for one day, and it set the stage for future collaboration between students and faculty of different departments."

- The conference led to increased interdepartmental interactions and collaborations as well as collaborations between Drake University and the nearby Des Moines Osteopathic School.

- The success of DUCURS has become a catalyst for organizing research in the sciences at Drake University. Initiatives are currently underway to organize and seek funding for a summer undergraduate research program, to submit a grant proposal to support interdisciplinary research, to develop an interdisciplinary seminar series, and to establish the Drake University Undergraduate Research Journal.

The overwhelming success of DUCURS is of course gratifying, but more importantly it is, we believe, a watershed event in the development of a culture of student-faculty research at Drake University. We look forward to future conferences and other projects and initiatives aimed at making undergraduate research an important priority. We realize that there is much to do and a long road ahead, but we are encouraged by the results of this first step.

About the Authors:

Dr. Heidi Sleister is Assistant Professor of Biology at Drake University, and can be reached at heidi.sleister@drake.edu. Dr. Charles Nelson is Assistant Professor of Physics and Astronomy at Drake University.

Dr. Maria Bohorquez is Associate Professor of Chemistry at Drake University. 